Trademark Notice: Product and corporate names may be trademarks or registered trademarks and are used only for explanation and to the owner's benefit, without intent to infringe.

For advertising rates and deadlines, contact the AECT offices, 812-335-7675.

Subscription information: TechTrends is published six times per year by Springer Science+Business Media, LLC. Volume 58 (6 issues) will be published in 2015.

ISSN: 8756-3894 (print version)

ISSN: 1559-7075 (electronic version)

Subscription Rates, Orders, Inquiries: Please contact the Springer Customer Service Center for the latest rates and information:

The Americas

(North, South, Central America, and the Caribbean):

Springer Journal Fulfillment

233 Spring Street

New York, NY 10013-1578, USA

TEL: 800-777-4643; 212-460-1500 (outside North America) E-MAIL: journals-ny@springer.com;

servicio-ny@springer.com (Central and South America)

\section{Outside the Americas:}

Springer Customer Service Center GmbH

Haberstrasse 7

69126 Heidelberg, GERMANY

TEL: 49-6221-345-4303

E-MAIL: subscriptions@springer.com

SpringerAlert Service: The SpringerAlert service is an innovative, free-of-charge service that notifies users via e-mail whenever new journals become available, and automatically sends the table of contents with direct links to the abstracts of papers in a newly published issue. Register for the SpringerAlert service at http://www.springerlink. com/alerting

(C)2015 Association for Educational Communications and Technology

Periodicals postage paid at New York, New York and additional mailing offices.

\section{Postmaster: Send address changes to:}

TechTrends, Springer

233 Spring Street

New York, NY 10013, USA.
From the Conference Planner

\author{
By Kay A. Persichitte, University of Wyoming
}

() Association for Educational Communications and Technology 2015

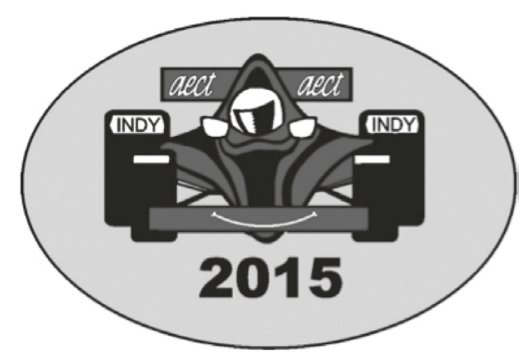

Our 2015 planning has reached top speed as we approach the final laps of our race to the convention in Indianapolis! We received a record number of proposals for sessions this year...over 980! Linda Mellish (Convention Co-Planner) and the 19-member Pit Crew (Program Planning Team) with the help of dozens of members have completed an extensive review process. The final program scheduling of hundreds of peer reviewed sessions is essentially complete and we are excited to welcome you in just a few weeks! Here are some program highlights to rev up your engine:

- Gráinne Conole (Bath Spa University) is our keynote speaker on the topic of Slow and Fast Learning with Contemporary Digital Technologies. She will also share her international expertise in a workshop session focused on preparing courses for online and mobile environments!

- About 40 renowned researchers, scholars, and leaders of our field will join us for the Breakfast with Champions!

- Tech Travesties returns after over a decade...join us for some fun as we spoof our field, our organization, and each other!

- Early registration numbers indicate that our international colleagues will join us in record numbers this year!

- Site tours of the Indiana Historical Society Museum, Indiana Museum of Arts, The Children's Museum of Indianapolis, and Indianapolis Motor Speedway and Hall of Fame Museum offer you both opportunities for fun and professional development!

- Workshops and Presidential Sessions will be delivered by internationally recognized contributors to the varied content specialty areas of our field!

- AECT Tech Saturday offers a full day of workshops and sessions especially for K-12 teachers, school media specialists, and administrators. [Co-sponsored by the SMT and TED Divisions and the Indiana State Teacher's Association]

See you November 3-7 as we work together to ACCELERATE LEARNING!

Kay

AECT President-Elect 